\title{
Optimal Sizing and Analysis of a Hybrid Energy System for a Community Microgrid in Nigeria
}

\author{
${ }^{1}$ Okhuegbe Samuel Nosakhale, ${ }^{2}$ Charles Mwaniki and ${ }^{3}$ Mudathir Funsho Akorede \\ ${ }^{1}$ Department of Electrical Engineering, Pan African University Institute for \\ Basic Science Technology and Innovation, Nairobi, Kenya \\ ${ }^{2}$ Department of Electrical and Electronic Engineering, Machakos University, Machakos, Kenya \\ ${ }^{3}$ Department of Electrical and Electronics Engineering, University of Ilorin, Ilorin, Nigeria \\ okhuegbe.samuel@students.jkuat.ac.ke,+254743607746
}

\begin{abstract}
This study focuses on determining the optimal size of each component of a hybrid energy system to meet the energy demand of Itele community in Nigeria at minimum Net Present Cost (NPC). The hybrid energy system consists of a solar photovoltaic, wind turbine and battery energy storage. HOMER was used as the optimization tool. In this research, the feasibility and optimal sizing of two different hybrid configurations were carried out. A standalone and an unreliable grid connected configuration was investigated and optimally sized. Also, a comparative study on the environmental effect was carried out. The results show that the unreliable grid connected mode had a NPC of $\$ 22.7$ million while the standalone system had an NPC of $\$ 29.9$ million. But based on environmental impact and emissions, the standalone system offered the cleanest system with zero carbon dioxide and sulfur oxide emission. While the unreliable grid connected system offered emission with $394.934 \mathrm{~kg} /$ year of carbon dioxide, $742 \mathrm{~kg} /$ year of nitrogen oxide and $1517 \mathrm{~kg} / \mathrm{year}$ of sulfur oxides.
\end{abstract}

$\underline{\text { Key words: Economic analysis, hybrid energy system, HOMER, microgrids, optimization, renewable energy }}$

\section{INTRODUCTION}

The demand for energy is increasing globally as a result of increased world population, industrialization, technology and urbanization. It is estimated that the world energy demand would increase by about $53 \%$ by 2035 (Smith et al., 2011). The demand for electricity in Africa is expected to quadruple by 2100 (Okundamiya, 2016). Nigeria which is the most populous African nation with about 195 million people (Worldometer, 2018), suffers greatly from inadequate power supply. According to the Africa Energy Outlook 2040 (PIDA., 2011), about 93 million people in Nigeria are without access to electricity. Also, areas that do have electricity access suffer from unreliable power supply coupled with the fact that majority of Nigeria's energy is gotten from fossil fuels which are unsustainable and affect the environment negatively in terms of $\mathrm{CO}_{2}$ emissions and greenhouse gases (Edomah, 2016). This creates a huge challenge on how to efficiently meet this energy need.

Various researchers have proposed the use of distributed renewable energy generation as a viable option to address this challenge also, the implementation of microgrids is seen as a good approach in solving the current energy crisis in Nigeria (Juma et al., 2018; Dada, 2014; Mohammed et al., 2013). A microgrid consists of a group of distributed energy resources and interconnected loads within clearly defined electrical boundaries that acts as a single controllable entity with respect to the grid. Microgrids can operate in either grid connected or stand-alone mode (Ton and Smith, 2012). The distributed energy sources in a microgrid can consist of either renewable energy source or conventional fossil-based energy sources. Renewable energy sources generally, face a drawback of being stochastic in nature and as such the use of a single renewable energy source cannot guarantee power supply. One way to tackle this drawback is through hybridization of renewable energy sources.

Hybrid energy systems describes a system in which different energy sources and energy storage systems are interconnected to supply the energy demand at a particular time in a particular location (Ariyo et al., 2018). Solar photovoltaic and wind energy are shown to be very good complements of each other (Okinda and Odero, 2016) and as such have been considered as viable renewable energy mix. One important challenge in the

Corresponding Author: Okhuegbe Samuel Nosakhale, Department of Electrical Engineering, Pan African University Institute for Basic Science Technology and Innovation, Nairobi, Kenya , okhuegbe.samuel@students.jkuat.ac.ke, +254743607746 
design of hybrid energy systems for microgrid application is determining the optimal size of each of the hybrid energy systems in the microgrid that would meet the energy demand at the most reduced cost. Oversizing would lead to an unnecessary increase in cost and under-sizing would create poor reliability with a lot of unmet energy demand (Krishna and Kumar, 2015), sizing renewable systems is further complicated by their intermittent nature. A lot of research has been carried out regarding optimal sizing of hybrid energy systems, researchers by Shahinzadeh et al. (2016) carried out optimal sizing of a grid connected microgrid using wind, solar and microturbine as the main power sources while battery and fuel cells constituted the storage system. The sizing was carried out for a location in Iran called Nain, it was discovered that the solar photovoltaic systems constituted the highest capital cost. Researchers by Ariyo et al. (2018) carried out sizing of a stand-alone hybrid energy system to efficiently meet the demand of the senate building of the University of Ilorin. Here, the HOMER Software was used, also the Fluke 432-II power quality and energy analyzer was used to $\log$ the hourly load consumption data of the case study building and two objectives of profit maximization and $\mathrm{CO}_{2}$ minimization were optimized. Genetic algorithm was used by researchers by Shahirinia et al. (2005) to optimally size a standalone hybrid energy system for reduced total annualized cost. The energy mixed included wind, solar photovoltaic, diesel and battery storage. The particle swarm optimization algorithm was used by Suryoatmojo et al. (2014) for optimally sizing a hybrid of solar, wind and battery for an isolated island. Researchers by Gonzalez et al. (2015) considered a hybrid grid connected photovoltaic and wind system without storage, cause the grid supplies power reliably when needed as back-up supply. From various literatures reviewed, the HOMER Software has proved to be quite accurate and as such it has gain wide prevalence. Also, there has been an observed scarcity of researches in grid connected hybrid energy systems when compared to stand-alone islanded systems. And in works that do consider a grid connected mode, the grid is assumed to be always available and reliable and this does not represent the reality of developing African countries like Nigeria. In this research optimal sizing in an unreliable grid would be investigated. The aim of this research is to determine the optimal size of each hybrid energy source that would meet the demand of the case study site at minimized Net Present Cost (NPC) and Cost of Energy (COE). In this research, optimal sizing and analysis would be carried out for two different hybrid energy system scenarios which include a stand-alone system and an unreliable grid connected hybrid energy systems. The Hybrid Optimization for Multiple Energy Resources (HOMER) would be used to carry out the optimization using real hourly load demand data of the select case study which is the Itele community in Nigeria. The optimal sizing would be carried out for minimized Net Present Cost (NPC) and Cost of Energy (COE). A hybrid of solar Photovoltaic (PV), Wind Turbine (WT) and battery energy storage is considered in this research. A comparative analysis would also be carried out for the two different hybrid energy system which would be useful to researchers and policy decision makers as regards the feasibility of hybrid energy systems as a viable solution to efficiently meet the demand of Itele community taking into consideration the cost of energy and environmental impact.

\section{MATERIALS AND METHODS}

Description of case study site: Itele, also known as Ijebu-Itele is a town in Ogun State Nigeria, about 286 miles $(460 \mathrm{~km})$ from Abuja, the country's capital. The community is part of Ijebu-East Local Government Area. Itele is located on latitude $6^{\circ} 46^{\prime} \mathrm{N}$ and longitude $4^{\circ} 03^{\prime} \mathrm{E}$. It is considered a traditional state because it is headed by a king (Oba) with the royal title of Moyegeso. The community is quite populated with over 4000 households, this comes as no surprise as Nigeria is the most populated African Nation of about 195 million in population (Smith et al., 2011). An aerial view of the case study site obtained from google Earth is shown in Fig. 1. Itele is largely a residential area.

\section{Load and resource assessment}

Load profile: A major aim for optimal sizing is to efficiently meet the energy demand, so, therefore, an understanding of the load demand is paramount. The hourly load demand for a year was obtained from Ikeja Electric PLC which is the distribution company operating around Itele. Figure 2 shows the plot of the hourly load demand data for a year. Itele has a peak load of about $4500 \mathrm{~kW}$ with an average load demand of about $2618 \mathrm{~kW}$. The average $\mathrm{kWh} /$ day is $62,834 \mathrm{kWh} /$ day.

Solar irradiance: The solar irradiance data is of great importance when modelling the output power from a solar photovoltaic. To synthesize the hourly solar irradiance, the monthly average solar irradiance was first, obtained from the power access data viewer of the National Aeronautic Space Agency (NASA) (NASA., 2019). The hourly solar irradiance was then synthesized from the averaged monthly irradiance using the HOMER Software as shown in Fig. 3. The minimum hourly irradiance was 


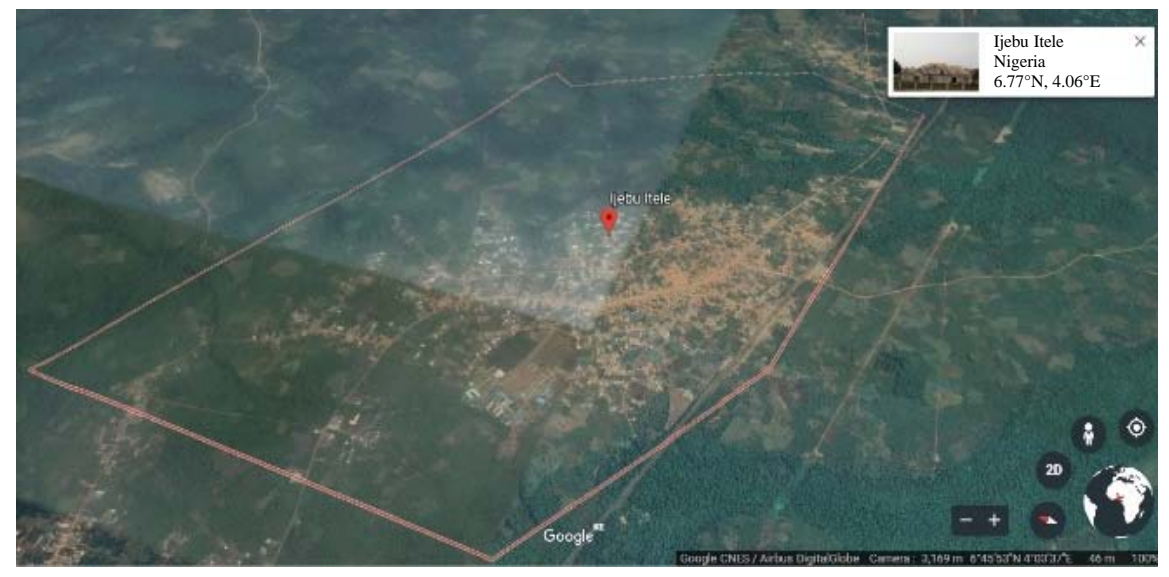

Fig. 1: Aerial view of Itele community in Ogun State Nigeria

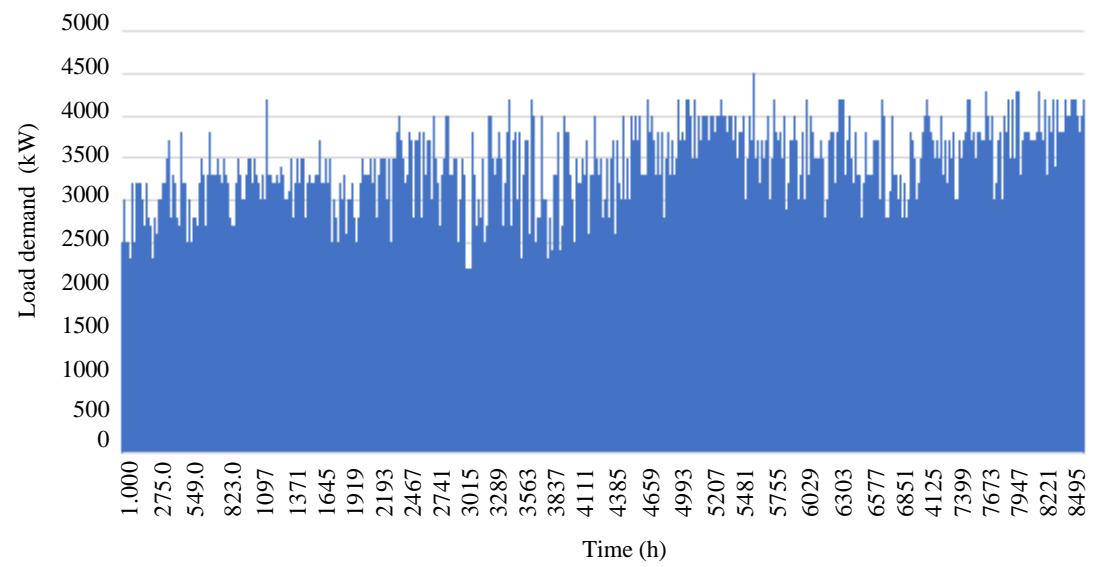

Fig. 2: Itele hourly load profile

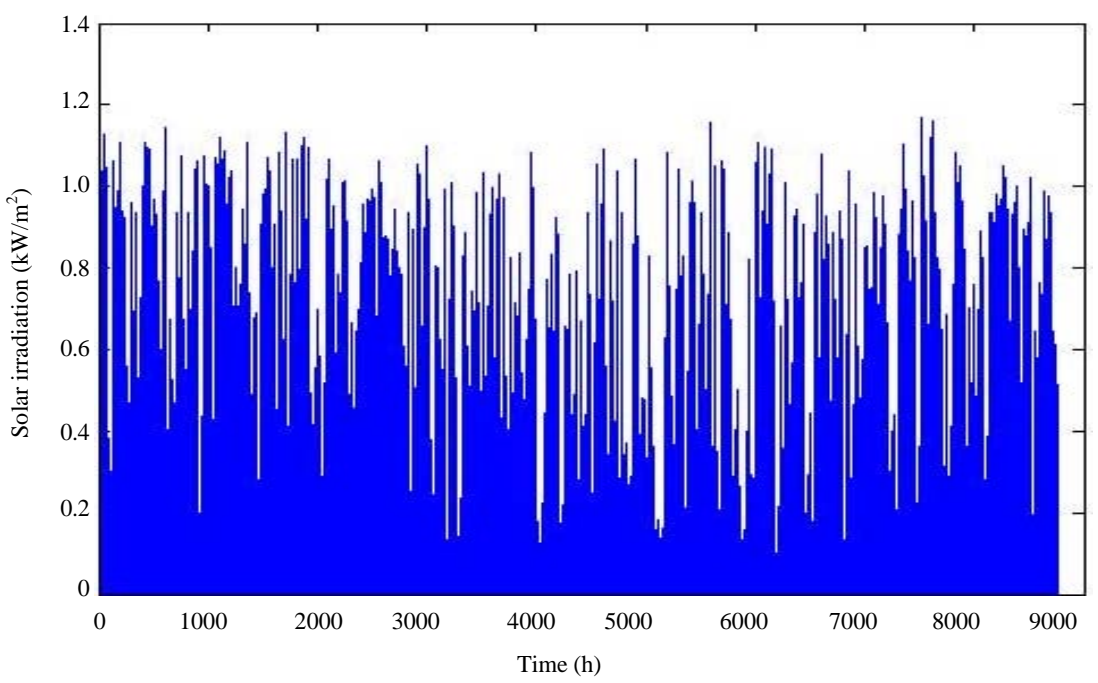

Fig. 3: Hourly solar irradiance for a year 


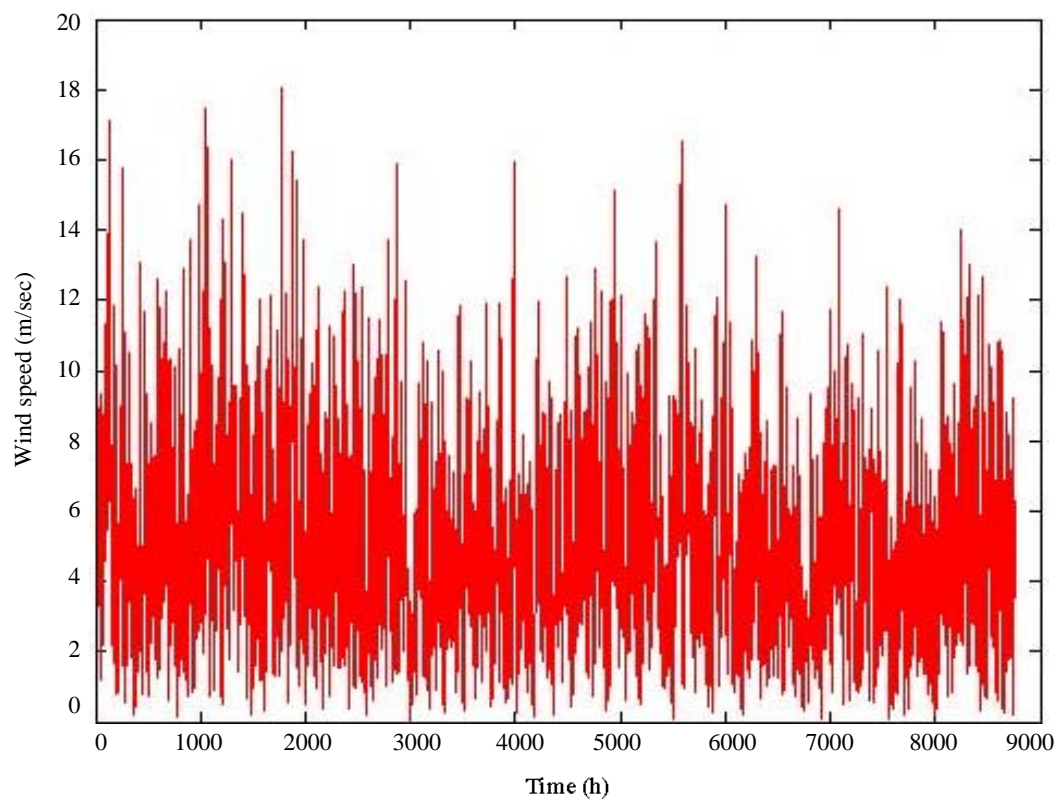

Fig. 4: Hourly wind speed profile

zero, this corresponds to the hour where there was no sunlight irradiance and the maximum hourly solar irradiance $1.16 \mathrm{~kW} / \mathrm{m}^{2}$ while the average hourly irradiance for the year corresponds to $0.1972 \mathrm{~kW} / \mathrm{m}^{2}$.

Wind speed: The hourly wind speed data for a year was equally synthesized from the average monthly wind speed data gotten from the Power Access Data Viewer (NASA., 2019). Here again, HOMER synthesizes the hourly wind speed. Figure 4 shows the hourly wind speed profile with an average hourly wind speed of about $6 \mathrm{~m} / \mathrm{sec}$.

System description: The layout for the hybrid energy system consists mainly of a solar PV, wind turbine, converter and battery energy storage. Both unreliable grid connected and standalone mode of connection would be analyzed. Figure 5 and 6 show the schematic diagram for an unreliable grid connected and stand-alone mode, respectively. For, the stand-alone Hybrid Energy System (HES), the aim is to supply power to meet the demand using the renewable energy powers from the solar PV and wind turbine with the battery storage employed only when the powers from the solar PV and wind turbine are insufficient to meet the load. The power balance is of great importance and acts a major constraint. The idea for an unreliable grid connected hybrid energy system is for the grid to act as a back-up for when power is unavailable from the hybrid energy sources due to their stochastic nature. Also, the grid provides an avenue to receive excess power, if produced. This means excess power can be sold back to the grid.

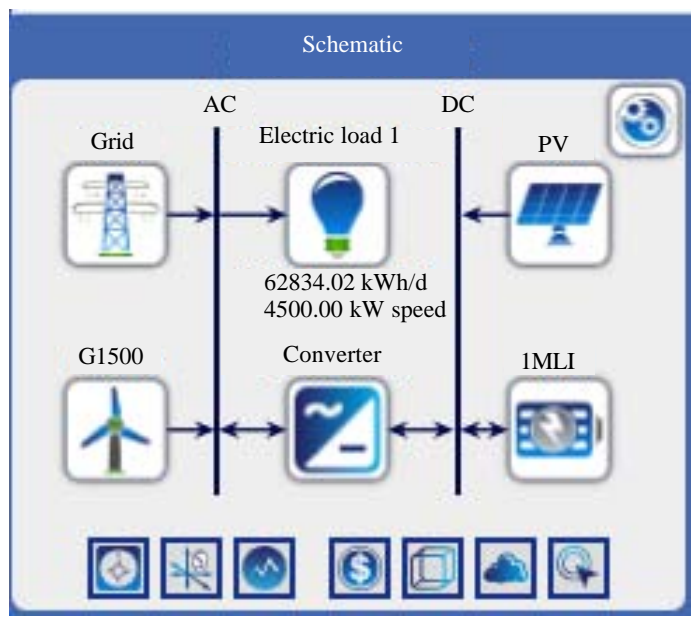

Fig. 5: Schematic for an unreliable grid connected microgrid with hybrid energy system

The unpredictable nature of the unreliable grid is considered, meaning when the grid power is unavailable, power cannot be bought from the grid. For both the stand-alone and unreliable grid connected, the load following dispatch strategy is employed.

System component modelling: In order to effectively determine the optimal size of each of the hybrid energy system component an accurate model of the power output of each component is required. 


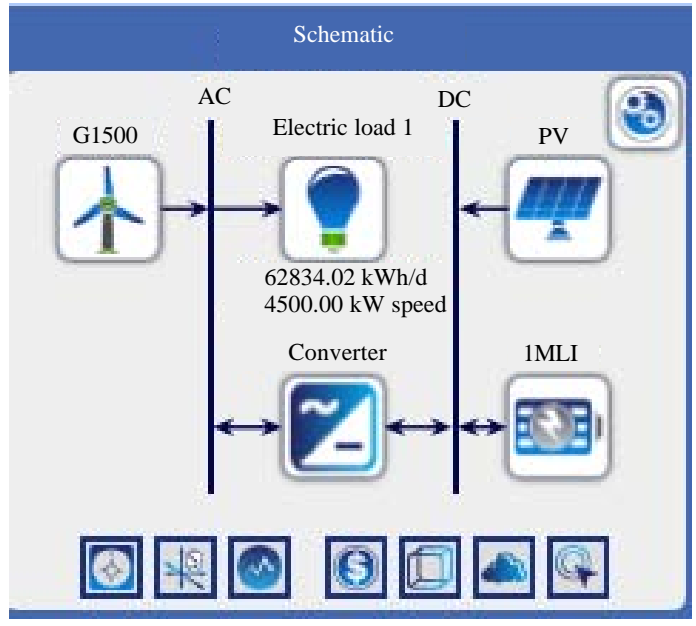

Fig. 6: Schematic for a stand-alone microgrid with hybrid energy system

Solar PV system model: The solar irradiation and temperature are the major factors that affect the output power of the solar PV. Solar PV output power is modelled by Homer (2019):

$$
\operatorname{Pp} v=\operatorname{Prp} v^{*} \operatorname{Dp} v *\left(\frac{\mathrm{Gt}}{\mathrm{Gstc}}\right) *(1+\propto(\mathrm{Tc}-\mathrm{Tstc}))
$$

Where:

Prpv $=$ The rated capacity of PV array $(\mathrm{kW}), \mathrm{Dpv}$ accounts for the derating factor $(\%)$

Gt $=$ The solar radiation incident on the PV panel $\left(\mathrm{kW} / \mathrm{m}^{2}\right)$

Gstc $=$ The incident radiation at standard test condition $\left(1 \mathrm{~kW} / \mathrm{m}^{2}\right)$

- $\quad=$ The temperature coefficient of power $\left(\% /{ }^{\circ} \mathrm{C}\right)$

$\mathrm{Tc}=$ The $\mathrm{PV}$ cell temperature and PV cell

Tstc temperature at standard test conditions

Wind turbine power system: The output power of the wind turbine is modelled based on the wind turbine power curve shown in Fig. 7 (Homer, 2019). From the curve we can see that the cut-in windspeed is about $3.75 \mathrm{~m} / \mathrm{sec}$ while the cut-out wind speed is $20 \mathrm{~m} / \mathrm{sec}$.

Battery energy storage: The battery energy storage is modelled in HOMER using the kinetic battery model (Manwell and McGowan, 1993). This determines the amount of energy that can be withdrawn or absorbed for each time step. The total amount of energy stored at any given hourly time step is a sum of the available energy $Q_{1}$ and bound energy $Q_{2}$ (Homer, 2019):

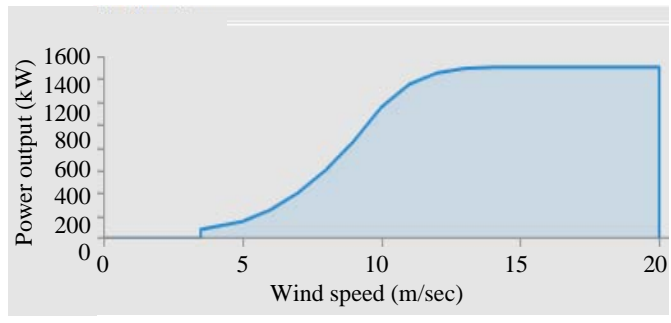

Fig. 7: Wind turbine power curve

$$
\mathrm{Q}=\mathrm{Q}_{1}+\mathrm{Q}_{2}
$$

The maximum amount of power that can be discharged for a given time step $\bullet t$ is given as:

$$
\mathrm{P}_{\text {bat, dmax }}=\frac{-\mathrm{KC}_{\max }+\mathrm{KQ}_{1} \mathrm{e}^{-\mathrm{k} \Delta \mathrm{t}}+\mathrm{QKC}\left(1-\mathrm{e}^{-\mathrm{k} \Delta \mathrm{t}}\right)}{1-\mathrm{e}^{-\mathrm{k} \Delta \mathrm{t}}+\mathrm{C}\left(\mathrm{K} \Delta \mathrm{t}-1+\mathrm{e}^{-\mathrm{k} \Delta \mathrm{t}}\right)}
$$

While the maximum amount of power that can be absorbed over a given time step $\bullet t$ is given as:

$$
\mathrm{P}_{\text {bat, C max }}=\frac{\mathrm{KQ}_{1} \mathrm{e}^{-\mathrm{k} \Delta \mathrm{t}}+\mathrm{QKC}\left(1-\mathrm{e}^{-\mathrm{k} \Delta \mathrm{t}}\right)}{1-\mathrm{e}^{-\mathrm{k} \Delta \mathrm{t}}+\mathrm{C}\left(\mathrm{K} \Delta \mathrm{t}-1+\mathrm{e}^{-\mathrm{k} \Delta \mathrm{t}}\right)}
$$

Equation 4 and 5 give the allowable ranges of power in and out of the battery storage. The actual available charge energy is given as:

$$
\mathrm{Q}_{1, \text { end }}=\mathrm{Q}_{1} \mathrm{e}^{-\mathrm{k} \Delta \mathrm{t}}+\frac{(\mathrm{QKC}-\mathrm{P})\left(1-\mathrm{e}^{-\mathrm{k} \Delta \mathrm{t}}\right)}{\mathrm{K}}+\frac{\mathrm{PC}\left(\mathrm{K} \Delta \mathrm{t}-1+\mathrm{e}^{-\mathrm{k} \Delta \mathrm{t}}\right)}{\mathrm{K}}
$$

While the discharge bound energy is given as:

$$
\begin{aligned}
Q_{2, \text { end }}= & Q_{2} \mathrm{e}^{-\mathrm{k} \Delta \mathrm{t}}+\frac{\mathrm{Q}(1-\mathrm{C})\left(1-\mathrm{e}^{-\mathrm{k} \Delta \mathrm{t}}\right)}{1}+ \\
& \frac{P(1-\mathrm{C})\left(\mathrm{k} \Delta \mathrm{t}-1+\mathrm{e}^{-\mathrm{k} \Delta \mathrm{t}}\right)}{\mathrm{K}}
\end{aligned}
$$

Where:

$\mathrm{Q}_{1} \quad=$ The available energy in $\mathrm{kWh}$ at the beginning of the time step $\cdot t$

$\mathrm{Q}_{2}=$ The bound energy in $\mathrm{kWh}$ at the beginning of the time step 


$$
\begin{aligned}
& Q_{1, \text { end }}=\text { The available discharge energy in } \mathrm{kWh} \text { at the } \\
& \text { end of the time step } \\
& \begin{aligned}
& Q_{2, \text { end }}= \text { The bound energy in } \mathrm{kWh} \text { at the end of the time } \\
& \text { step } \\
& \mathrm{P}=
\end{aligned} \\
& \begin{array}{l}
\text { The power in } \mathrm{kW} \text { into or out of the battery } \\
\text { storage }
\end{array}
\end{aligned}
$$

Grid power output: In this research grid power output is considered when unreliable. Previous version of the HOMER Software was capable of implementing only a reliable grid mode and as such a lot of works on grid connected hybrid energy system assumed the grid to be always available. Generally, the power supplied by the grid is expressed as Singh and Kaushik (2016):

$$
\mathrm{P}_{\mathrm{gp}(\mathrm{t})}=\mathrm{P}_{\text {load }(\mathrm{t})}-\sum \mathrm{P}_{\mathrm{hg}(\mathrm{t})}
$$

Where:

$\mathrm{P}_{\mathrm{gp}} \quad=$ The power supplied by the grid

$\mathrm{P}_{\text {load }(t)}=$ The load demand at time step $\mathrm{t}$

$\mathrm{P}_{\mathrm{hg}(t)}=$ The power output from all other hybrid energy generation sources which in this case are the power output from the solar PV, wind turbine and battery storage

A time step of one hour is used in this research, spanning an entire year. In the case of an unreliable grid, random time steps with grid outages based on the mean outage frequency and mean time to repair are specified. A flag is set that randomly toggles between 1 and 0 (Homer, 2019). A flag of 1 indicates the grid is available and operational and as such it can supply power while a 0 indicates the grid is unavailable:

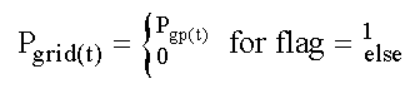

Cost function and constraints: The major objective of optimal sizing is to determine the optimal size of each power source that would meet the load at minimum cost and as such the cost function is extremely important. The two cost functions which are calculated are the Net Present Cost (NPC) and the Cost of Energy (COE).

Net Present Cost (NPC) function: The cost function here is the net present cost. HOMER ranks the sizing of hybrid energy systems based on the Net Present Cost (NPC). The NPC is given as:

$$
(\mathrm{NPC})=\frac{\mathrm{C}_{(\mathrm{a}, \text { tot })}}{\left|\frac{\left[\mathrm{i}(1+\mathrm{i})^{\mathrm{N}}\right.}{\left((1+\mathrm{i})^{\mathrm{N}}\right.}-1\right|}
$$

Where:

$\mathrm{C}_{\mathrm{a} \text {, tot }}=$ The total annualized cost

$\mathrm{i}=$ The interest rate

$\mathrm{N}=$ The project life time

Cost of Energy (COE): The levelized Cost of Energy (COE) is the average cost per kWh of useful electrical energy produced by the system. It is represented as shown in Eq. 10:

$$
\mathrm{COE}=\frac{\mathrm{C}_{\mathrm{a}, \text { tot }}}{\mathrm{E}_{\text {served }}}
$$

$E_{\text {served }}$ is the total electrical load served.

Constraints: The major constraints are the power balance constraints, solar PV power, number of wind turbine and battery limits. The upper and lower bounds of the limits are specified in the HOMER optimizer:

$$
\begin{gathered}
\mathrm{P}_{\mathrm{pv}}+\mathrm{P}_{\mathrm{wt}}+\mathrm{P}_{\text {bat }}+\mathrm{P}_{\text {grid }} \geq \mathrm{P}_{\text {load }} \\
\mathrm{P}_{\mathrm{p} v_{\text {min }}} \leq \mathrm{P}_{\mathrm{p} v} \leq \mathrm{P}_{\mathrm{p} v_{\text {max }}} \\
\mathrm{Nwt}_{\text {min }} \leq \mathrm{Nwt} \leq \mathrm{Nwt}_{\text {max }} \\
\mathrm{Nbat}_{\text {min }} \leq \mathrm{Nbat} \leq \mathrm{Nbat}_{\text {max }}
\end{gathered}
$$

\section{HOMER Software tool and operation}

HOMER stands for hybrid optimization for multiple energy resources: It is an optimization tool originally developed at the National Renewable Energy Lab (NREL). It has been widely used and accepted as an accurate tool to perform techno-economic analysis on hybrid energy systems in a microgrid (Bahramara et al., 2016). HOMER can be used to carry out optimization and several techno-economic analyses such as sensitivity analysis. HOMER can also be used to synthesize hourly solar and wind speed data which can be exported as a csv file. It has the capability to size different forms of energy sources which include solar PV, wind turbines, generators, fuel cells, battery, boiler and hydro. The main data required for optimal sizing are the meteorological data, load demand data and the system specification data. The result from the HOMER analysis contains the optimal individual size of each of the hybrid power sources considered and the minimized net present cost and cost of energy. Mathematical models of each power component is carried out to determine their output. HOMER iterate between all feasible combinations and 
configurations of the hybrid energy system and ranks them based on the NPC. Table 1 shows the parameters and specifications used in this research. The lifetime of the design is specified at 20 years.

Table 1: Data parameters and variables used (Adefarati and Bansal) Birkhimer)

\begin{tabular}{ll}
\hline Parameters & Specifications \\
\hline Project lifetime & 20 years \\
Nominal discount rate & $10 \%$ \\
Dispatch strategy & Load following \\
PV capital cost & $\$ 1300 / \mathrm{kW}$ \\
PV O\&M cost & $\$ 10 /$ year \\
PV lifetime & 20 years \\
PV derating factor & $90 \%$ \\
WT capital cost & $\$ 2000000$ \\
WT rated capacity (G1500) & $1500 \mathrm{~kW}$ \\
WT O\&M & $\$ 2500 /$ year \\
WT lifetime & 20 years \\
Battery capital cost & $\$ 200000$ \\
Battery round trip efficiency & $90 \%$ \\
Battery nominal capacity & $1000 \mathrm{kWh}$ \\
Battery max discharge current & $1.67 \mathrm{E}+03$ \\
Battery nominal voltage & $600 \mathrm{~V}$ \\
Converter & $\$ 300 / \mathrm{kW}$ \\
Converter replacement cost & $\$ 300 / \mathrm{kW}$ \\
Converter lifetime & 10 years \\
Converter efficiency & $96 \%$ \\
\hline
\end{tabular}

\section{RESULTS AND DISCUSSION}

Stand-alone: The results from the standalone hybrid energy system which consists of solar PV, wind turbine, battery energy storage and converter are discussed here. The results show an optimal size of four $1500 \mathrm{~kW}$ wind turbine, $6891 \mathrm{~kW}$ of solar PV, fifty-two $1000 \mathrm{kWh}$ batteries, $5073 \mathrm{~kW}$ of converter with a Net Present Cost (NPC) of $\$ 29.9$ million and a COE of $\$ 0.131$. Figure 8 and 9 shows a heat map of the hourly power output of the solar $\mathrm{PV}$ and wind turbine, respectively for a year (365 days). The standalone system has zero emissions from carbon dioxide, carbon monoxide, nitrogen oxide, unburned hydrocarbon and sulfur oxide.

Unreliable grid connected mode: For an unreliable grid connected mode, a mean outage frequency of 100 /year and a mean repair time of $1 \mathrm{~h}$ was considered. In this mode, the idea is to power the system with renewable energy as much as possible while using the grid as back up to supply power when the renewable energy sources are unable to provide power. It also has the advantage that excess power can be sold back to the grid, this helps

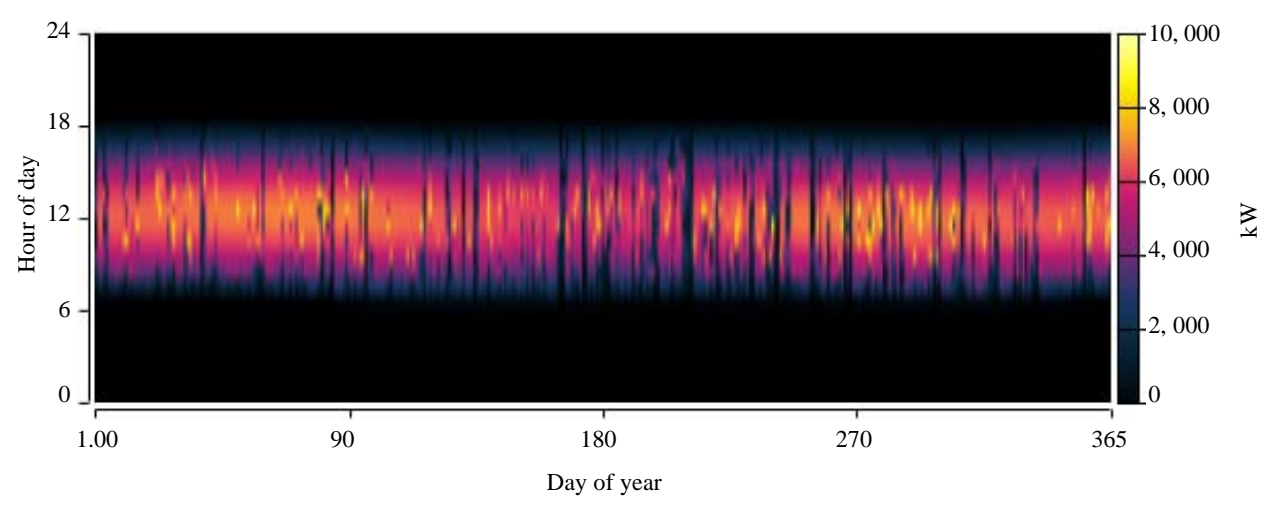

Fig. 8: Hourly solar PV power output for a year in standalone mode

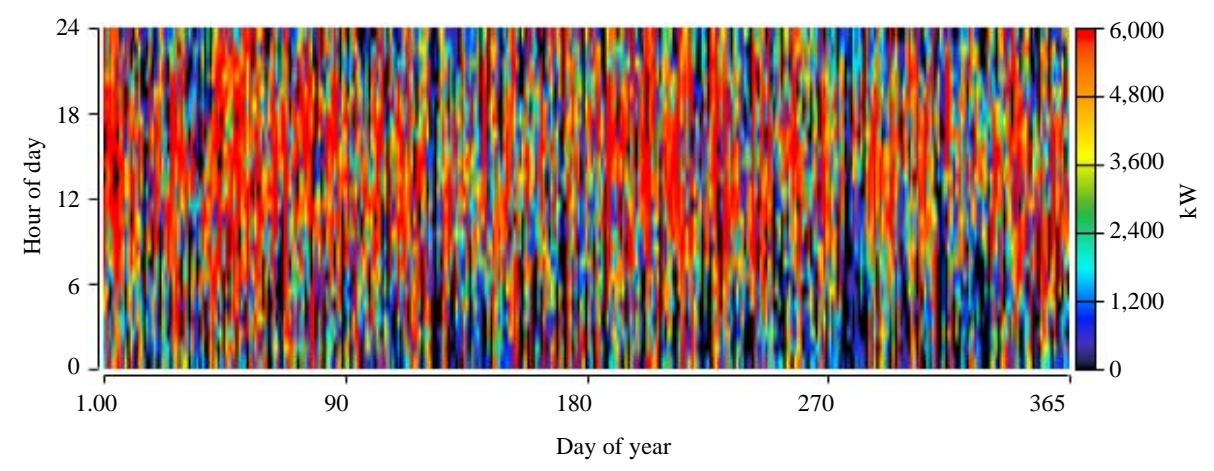

Fig. 9: Hourly wind turbine output for a year in stand-alone mode 


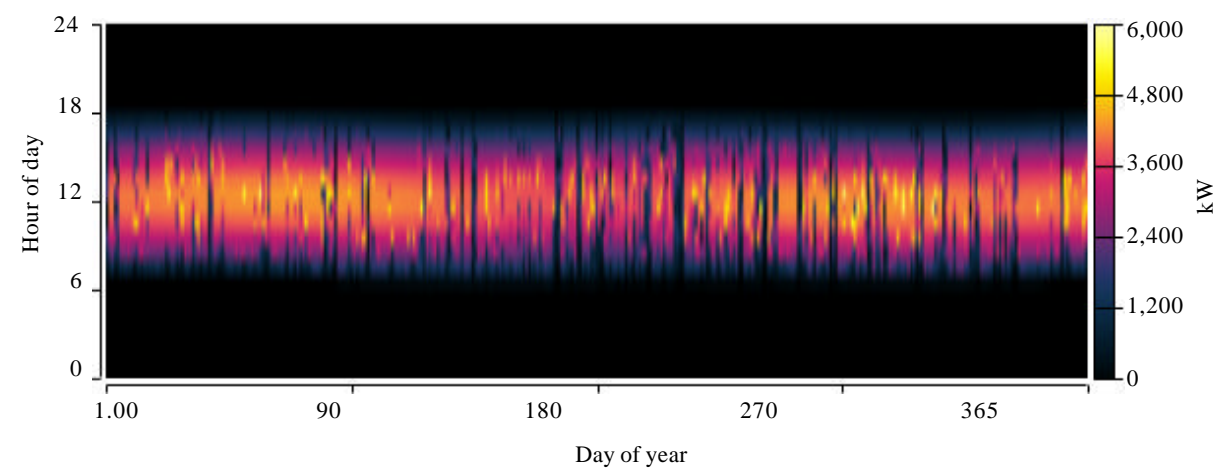

Fig. 10: Heat map showing the hourly PV power output in an unreliable grid connected mode

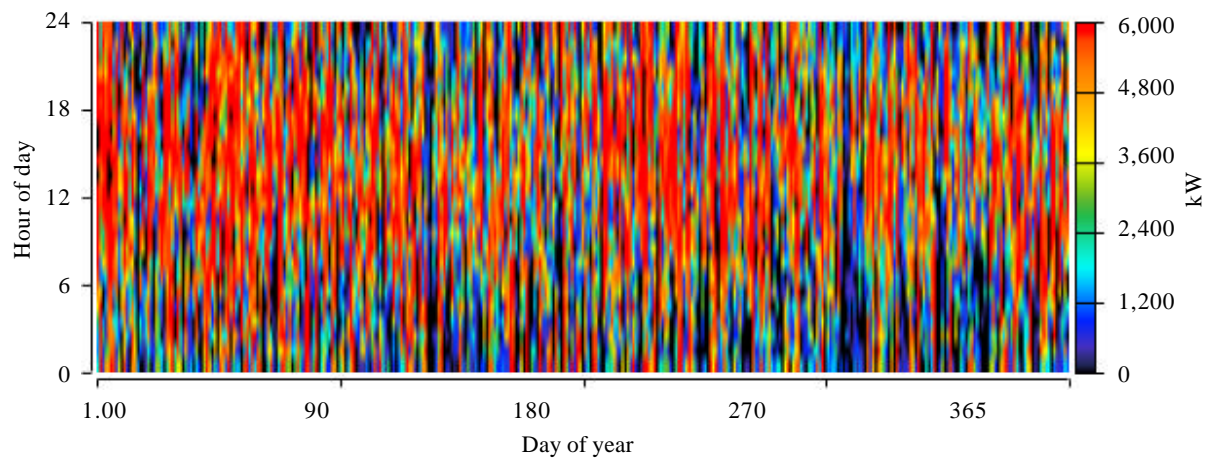

Fig. 11: Hourly wind turbine output in unreliable grid connected mode

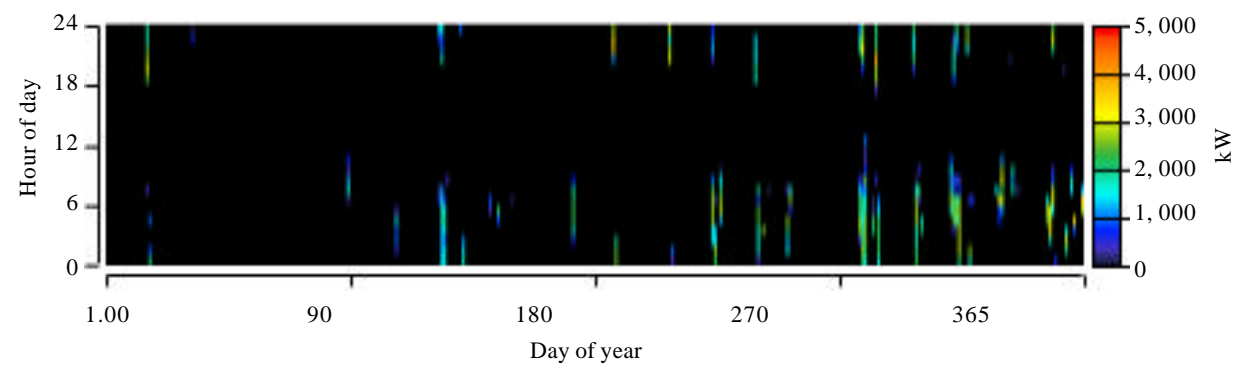

Fig. 12: Hourly energy purchased from the unreliable grid

in reducing the Net Present Cost (NPC). Though at time steps when the grid is unavailable, power cannot be bought from the grid.

The results show an optimal size of $4304 \mathrm{~kW}$ of solar $\mathrm{PV}$, four $1500 \mathrm{~kW}$ of wind turbine, thirty-four $1000 \mathrm{kWh}$ of battery and $4066 \mathrm{~kW}$ of converter with an NPC of $\$ 22.7$ million and a COE of $\$ 0.0510$. The energy purchased amounted to $553.694 \mathrm{kWh}$ while the energy sold amounted to $15,498.052 \mathrm{kWh}$. The NPC for the unreliable grid connected hybrid system is about $24 \%$ lesser than that of the stand-alone system. In terms of environmental impact, the system produced $394.934 \mathrm{~kg} /$ year of carbon dioxide, $1517 \mathrm{~kg} /$ year of sulfur dioxide and $742 \mathrm{~kg} /$ year of nitrogen oxide. Figure 10 and 11 show the solar PV power output and wind turbine power output, respectively. From Fig. 12 and 13, we can notice that less amount of energy was purchased from the unreliable grid as compared to the energy sold back to the grid.

Comparison of standalone and unreliable grid connected mode: Table 2 shows the comparison of the results obtained from the simulation of standalone and an unreliable grid connected hybrid energy system. In terms of cost, the unreliable grid system connected with the renewable hybrid energy system offered a cheaper NPC which is about $24 \%$ lesser than the standalone system 


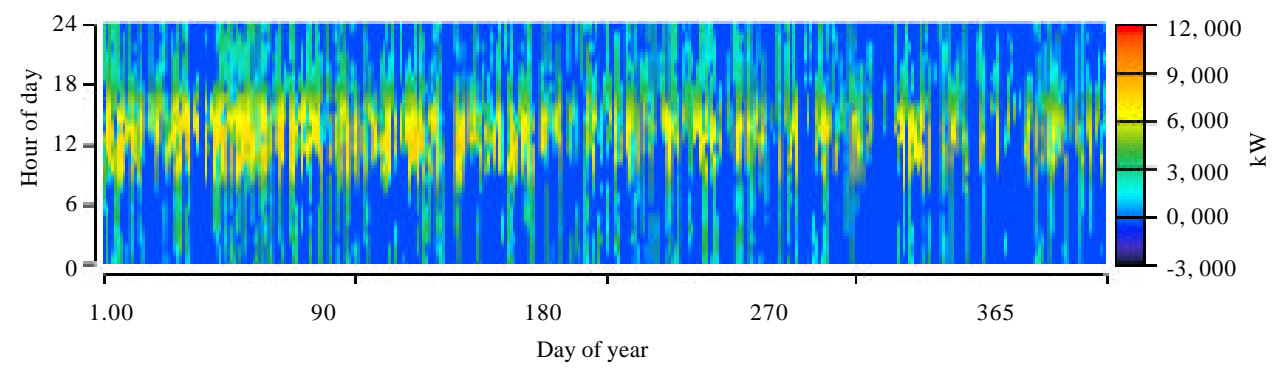

Fig. 13: Hourly energy sold back to the unreliable grid

\begin{tabular}{lll} 
Table 2: Comparison of results & & \\
\hline Parameters & Stand-alone & Unreliable grid \\
\hline NPC (\$) & $\$ 29.9$ million & $\$ 22.7$ million \\
COE (\$) & $\$ 0.131$ & $\$ 0.0510$ \\
Solar PV (kW) & $6891 \mathrm{~kW}$ & $4304 \mathrm{~kW}$ \\
Number of wind turbine & $4 \mathrm{No}$. & $4 \mathrm{No}$. \\
Number of batteries & $52 \mathrm{No}$. & $34 \mathrm{No}$. \\
Energy purchased from grid (kWh) & 0 & $553.694 \mathrm{kWh}$ \\
Energy sold to grid (kWh) & 0 & $15.498,052 \mathrm{kWh}$ \\
Carbon dioxide emission (kg/year) & 0 & $394.934 \mathrm{~kg} / \mathrm{year}$ \\
Sulfur dioxide emission (kg/year) & 0 & $1517 \mathrm{~kg} / \mathrm{year}$ \\
Nitrogen oxides emission (kg/year) & 0 & $742 \mathrm{~kg} / \mathrm{year}$ \\
\hline
\end{tabular}

and in terms of COE, the unreliable grid system was also lesser than the standalone hybrid system. In terms of environmental impact, the unreliable grid systems offered some emissions. The stand-alone system still offers the cleanest form of power, although, at a slightly higher cost.

\section{CONCLUSION}

In this research, optimal sizing of hybrid energy systems under standalone mode and unreliable grid connected mode has been performed. The hybrid system considered are a combination of solar PV, wind turbine and battery energy storage. The simulation was performed using HOMER and from our analysis we can see that the unreliable grid connected system is cheaper in terms of cost, than the standalone hybrid system. In terms of environmental impact, the stand-alone system offered zero carbon dioxide, sulfur dioxide and nitrogen oxide.

\section{ACKNOWLEDGEMENT}

The researchers acknowledge the technical and financial support of the Pan African University Institute for Basic Sciences, Technology and Innovation, Kenya.

\section{REFERENCES}

Ariyo, B.O., M.F. Akorede, I.O.A. Omeiza, S.A.Y. Amuda and S.A. Oladeji, 2018. Optimisation analysis of a stand-alone hybrid energy system for the senate building, University of Ilorin, Nigeria. J. Build. Eng., 19: $285-294$.
Bahramara, S., M.P. Moghaddam and M.R. Haghifam, 2016. Optimal planning of hybrid renewable energy systems using HOMER: A review. Renewable Sustainable Energy Rev., 62: 609-620.

Dada, J.O., 2014. Towards understanding the benefits and challenges of Smart/Micro-Grid for electricity supply system in Nigeria. Renewable Sustainable Energy Rev., 38: 1003-1014.

Edomah, N., 2016. On the path to sustainability: Key issues on Nigeria's sustainable energy development. Energy Rep., 2: 28-34.

Gonzalez, A., J.R. Riba, A. Rius and R. Puig, 2015. Optimal sizing of a hybrid grid-connected photovoltaic and wind power system. Appl. Energy, 154: 752-762.

Homer, 2019. Homer help manual. HOMER Energy, Boulder, Colorado, USA. https://www.homerenergy. com/products/pro/docs/3.13/index.html

Juma, S.A., C.M. Muriithi and L.M. Ngoo, 2018. Optimal switching sequence using a metaheuristic algorithm for feeder reconfiguration. Intl. J. Eng. Res. Technol., 11: 1329-1346.

Krishna, K.S. and K.S. Kumar, 2015. A review on hybrid renewable energy systems. Renewable Sustainable Energy Rev., 52: 907-916.

Manwell, J. and J. McGowan, 1993. Lead acid battery storage model for hybrid energy systems. Solar Energy, 50: 399-405.

Mohammed, Y.S., M.W. Mustafa, N. Bashir and A.S. Mokhtar, 2013. Renewable energy resources for distributed power generation in Nigeria: A review of the potential. Renewable Sustainable Energy Rev., 22: 257-268.

NASA., 2019. Power access data viewer. National Aeronautics and Space Administratio, Washington, DC., USA.

Okinda, V.O. and N.A. Odero, 2016. Modelling, simulation and optimal sizing of a hybrid wind, solar PV power system in Northern Kenya. Intl. J. Renewable Energy Res., 6: 1199-1211.

Okundamiya, M.S., 2016. Power electronics for grid integration of wind power generation system. J. Commun. Technol. Electron. Comput. Sci., 9: $10-16$. 
PIDA., 2011. Africa energy sector outlook-2040. Programme for Infrastructure Development in Africa (PIDA), Africa. http://webcache.googleusercontent. com/search?q=cache:AtIug 4sfm9cJ:db.foresight.kr/ sub03/research/filedown/id/1252/field/file_saved_n ame/rfile/56bd48003ecef56f568bl 48064d4b36c+\&cd $=3 \& \mathrm{hl}=\mathrm{en} \& \mathrm{c}$

Shahinzadeh, H., M. Moazzami, S.H. Fathi and G.B. Gharehpetian, 2016. Optimal sizing and energy management of a grid-connected microgrid using HOMER software. Proceedings of the 2016 Smart Grids Conference (SGC), December 20-21, 2016, EEE, Kerman, Iran, ISBN:978-1-5090-4989-9, pp: 1-6.

Shahirinia, A.H., S.M.M. Tafreshi, A.H. Gastaj and A.R. Moghaddomjoo, 2005. Optimal sizing of hybrid power system using genetic algorithm. Proceedings of the 2005 International Conference on Future Power Systems, November 18, 2005, IEEE, Amsterdam, Netherlands, ISBN:90-78205-02-4, pp: 1-6.
Singh, S. and S.C. Kaushik, 2016. Optimal sizing of grid integrated hybrid PV-biomass energy system using artificial bee colony algorithm. IET. Renewable Power Gener., 10: 642-650.

Smith, K.A., J.L. Barden, P.D. Martin, J.L. Barden and D.R. Kearney et al., 2011. International energy outlook 2011. US Energy Information Administration, Washington, DC., USA. http://arge.stanford.edu/ courses/2011/ph240/nagasawa2/docs/0484-2011.pdf

Suryoatmojo, H., A.A. Elbaset, F.A. Pamuji, D.C. Riawan and Nursalim et al., 2014. Optimal sizing and control strategy of hybrid PV-diesel-battery systems for isolated island. Electr. Eng., 1: 1-6.

Ton, D.T. and M.A. Smith, 2012. The US Department of 3energy's microgrid initiative. Electricity J., 25: 84-94.

Worldometer, 2018. Nigeria population. Worldometers, Nigeria. https://www.worldometers.info/worldpopulation/nigeria-population/ 